\title{
SEVERE INFANTILE HYPERCALCAEMIA WITH SPECIAL REFERENCE TO THE FACIES
}

BY

\author{
M. C. JOSEPH and D. PARROTT \\ From the Department of Child Health, Guy's Hospital
}

(RECEIVED FOR PUBLICATION APRIL 30, 1958)

In 1932 Lightwood described a child aged 2 years whose illness resembled the terminal stages of severe infantile hypercalcaemia. Later Butler (1951) and Fanconi (1951) each reported similar cases and they then discussed their findings in a joint paper (Fanconi, Girardet, Schlesinger, Butler and Black, 1952). Since then there have been several reports of the severe form of this disease in this country (Creery, 1953; Dawson, Craig and Perera, 1954; Lowe, Henderson, Park and McGreal, 1954; Russell and Young, 1954; Schlesinger, Butler and Black, 1956). The incidence in America is less but recently a few cases have been reported (Sissman and Klein, 1956; Daeschner and Daeschner, 1957; Bongiovanni, Eberlein and Jones, 1957).

Lightwood and Stapleton (1953) believed that the severe type of infantile hypercalcaemia was a different syndrome from the mild type and they suggested that each should be labelled descriptively until more was known about them. They pointed out that in the mild form (Lightwood, 1952; Payne, 1952), the prognosis was good, but that in the severe form renal damage and mental retardation commonly occurred. This division into mild and severe forms is probably artificial because gradations between the two forms have emerged. We here describe three infants who were severely affected, and, in support of the conception of intermediate forms, a fourth infant who was moderately severely affected; in addition, this infant showed some of the features of infantile renal acidosis (Lightwood, 1935). We also report our observations on the facies as it is often a prominent and diagnostic feature of the disease.

\section{Case Histories}

Case 1. B.G. was the second child of healthy parents. Pregnancy and delivery were normal, and her birth weight was $7 \mathrm{lb} .12 \mathrm{oz}$. She was breast fed for the first three weeks, and then as lactation failed she was fed on National Dried Milk, half cream for six weeks and subsequently full cream. About 400 units of vitamin D
(National Cod Liver Oil compound) were given daily.

Vomiting dated from birth, and usually occurred about half an hour after a feed; it was often bile stained. Initially she took her feeds fairly well but as her gain in weight was unsatisfactory she was admitted to a hospital at the age of 3 months; while there regurgitation occurred and a barium meal was normal; she was discharged home after four days. Her vomiting and failure to thrive continued, and at the age of 4 months one of us first saw her at an infant welfare clinic. Her weight was then $9 \mathrm{lb} .14 \mathrm{oz}$., and physical examination showed an apathetic infant, with a wide mouth, epicanthic folds and a concomitant squint (Fig. 1); a loud blowing systolic

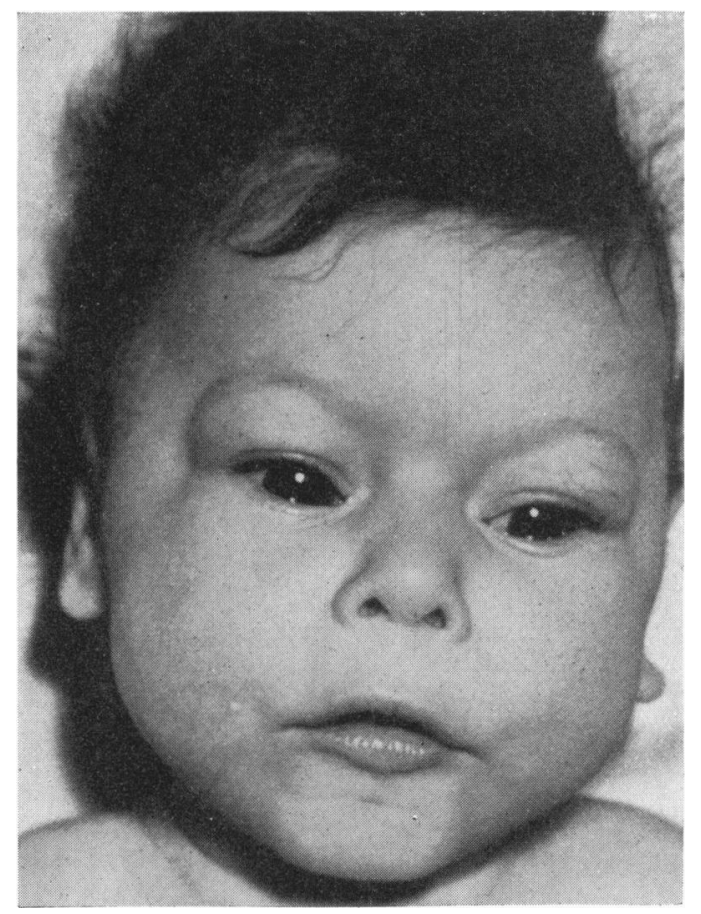

FIG. 1.-The facial appearance. 


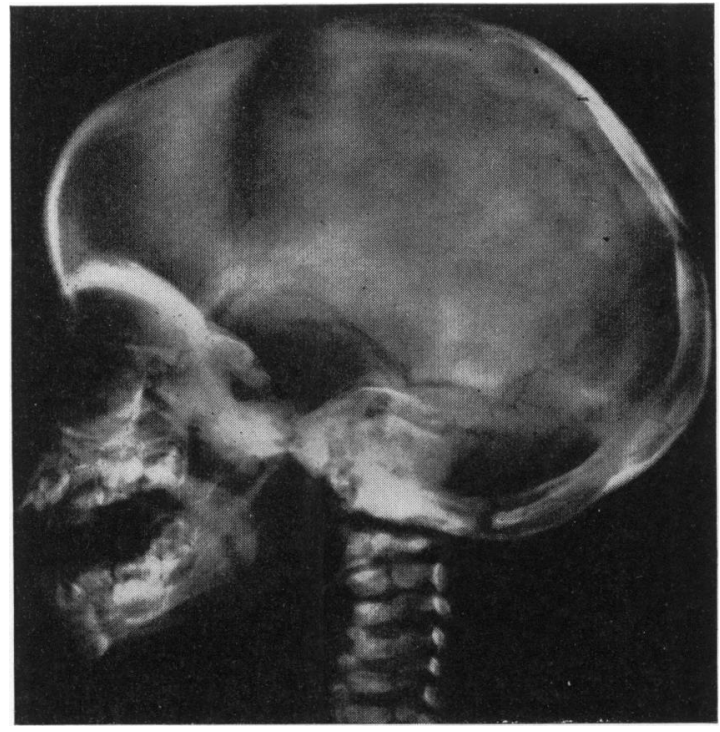

FIg. 2.-Case 1. Increased density at the base of the skull.

murmur internal to the apex was present and the systolic blood pressure was $130 \mathrm{~mm}$. Hg. A provisional diagnosis of severe infantile hypercalcaemia was made and she was admitted to Guy's Hospital for further investigation.

INVESTIGATIONS. The results of investigations on admission are shown in Table 1 . The main abnormality was the raised blood urea. The serum calcium was regarded as a high normal. The serum cholesterol was normal. The electrolytes were normal. Radiographs of

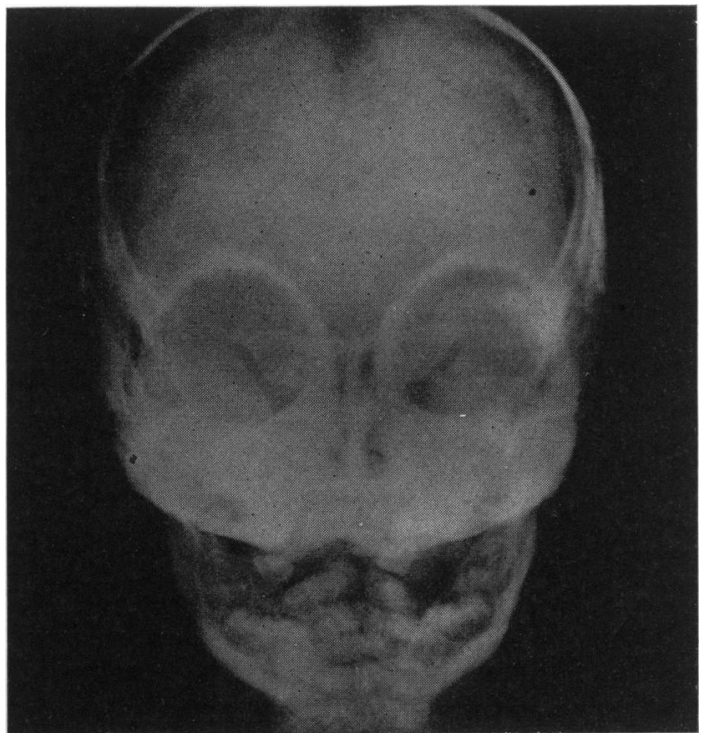

FIG. 3.-Case 1. Increased density of the periorbital bones.

the skeleton showed increased density at the base of the skull (Fig. 2), of the periorbital bones (Fig. 3), at the ends of the long bones and the upper and lower borders of the vertebrae.

Serial biochemical estimations were made over the first five weeks (Table 2). Four weeks after admission the serum calcium level was unequivocally raised to $13.3 \mathrm{mg} . \%$. The serum cholesterol was normal on three occasions (132 mg. \%, $125 \mathrm{mg}$. \%, and $117 \mathrm{mg}$. \%).

TABLE 1

EARLY INVESTIGATIONS

\begin{tabular}{|c|c|c|c|c|c|c|c|c|c|c|c|c|c|c|c|c|c|c|c|c|c|c|}
\hline \multirow[b]{2}{*}{$\begin{array}{l}\dot{0} \\
z \\
\ddot{z} \\
\tilde{U}\end{array}$} & \multirow[b]{2}{*}{ 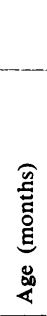 } & \multicolumn{2}{|c|}{$\begin{array}{l}\text { Blood } \\
\text { Count }\end{array}$} & \multicolumn{4}{|c|}{ Urine } & \multicolumn{6}{|c|}{ Blood Chemistry } & \multicolumn{9}{|c|}{$\begin{array}{l}\text { Radiographs showing } \\
\text { increased Density }\end{array}$} \\
\hline & & 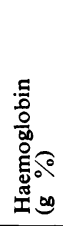 & 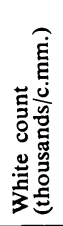 & 采 & 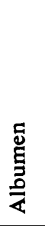 & 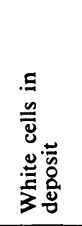 & $\frac{\stackrel{\Xi}{コ}}{3}$ & 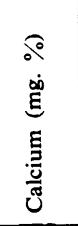 & 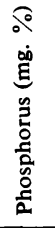 & 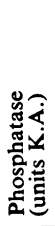 & 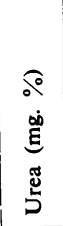 & 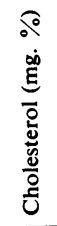 & 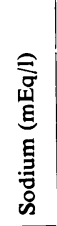 & 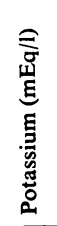 & 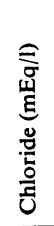 & 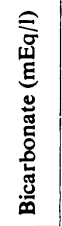 & 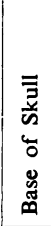 & 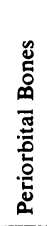 & 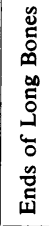 & 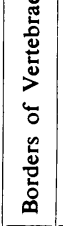 & $\frac{n}{2}$ & $\stackrel{\mathscr{0}}{\stackrel{0}{\alpha}}$ \\
\hline 1 & $\begin{array}{l}4 \\
5\end{array}$ & $11 \cdot 2$ & 10 & acid & nil & \pm & - & $\begin{array}{l}11 \cdot 4 \\
13 \cdot 3\end{array}$ & $\begin{array}{l}4 \cdot 2 \\
9 \cdot 6\end{array}$ & $\begin{array}{l}13 \\
16\end{array}$ & $\begin{array}{r}57 \\
100\end{array}$ & $\begin{array}{l}132 \\
117\end{array}$ & 137 & $4 \cdot 4$ & $\begin{array}{l}101 \\
101\end{array}$ & $\begin{array}{l}19 \cdot 8 \\
20 \cdot 4\end{array}$ & yes & yes & yes & yes & no & no \\
\hline 2 & 5 & $9 \cdot 5$ & 27 & 4 & + & + & - & 13 & 3 & 6 & 97 & 160 & 152 & $3 \cdot 7$ & 102 & 24 & yes & yes & yes & no & no & no \\
\hline 3 & $\begin{array}{l}24 \\
60\end{array}$ & & & $\stackrel{8}{\text { acid }}$ & $\begin{array}{l}\text { nil } \\
\text { nil }\end{array}$ & - & - & $\begin{array}{r}12 \cdot 4 \\
9 \cdot 5 \\
\end{array}$ & $6 \cdot 2$ & 21 & $\begin{array}{r}133 \\
73 \\
\end{array}$ & $\begin{array}{l}320 \\
302 \\
\end{array}$ & & & 97 & $22 \cdot 5$ & $\begin{array}{c}\text { yes } \\
\text { no }\end{array}$ & $\begin{array}{r}\text { yes } \\
\text { no }\end{array}$ & yes & $\begin{array}{c}\text { yes } \\
\text { no }\end{array}$ & $\begin{array}{l}\text { no } \\
\text { no }\end{array}$ & $\begin{array}{l}\text { no } \\
\text { no }\end{array}$ \\
\hline 4 & $\begin{array}{r}5 \frac{1}{2} \\
7 \\
12\end{array}$ & $10 \cdot 8$ & 12 & $\begin{array}{c}6 \\
\text { neutral }\end{array}$ & $\begin{array}{l}\text { nil } \\
+\end{array}$ & $\begin{array}{c}t+t \\
+t\end{array}$ & $\begin{array}{l}\text { Esch. } \\
\text { coli } \\
\text { Proteus }\end{array}$ & $\begin{array}{c}10 \cdot 9 \\
11 \cdot 5 \\
11 \cdot 2 \\
14 \\
9 \\
15 \cdot 8 \\
14 \cdot 6\end{array}$ & & & $\begin{array}{r}35 \\
60 \\
130\end{array}$ & $\begin{array}{l}315 \\
200\end{array}$ & 146 & $4 \cdot 6$ & $\begin{array}{l}109 \\
113 \\
113\end{array}$ & $\begin{array}{c}16 \\
18 \cdot 8 \\
18 \cdot 8\end{array}$ & yes & yes & yes & yes & $\begin{array}{l}\text { yes } \\
\text { yes }\end{array}$ & $\begin{array}{l}\text { no } \\
\text { no } \\
\text { no }\end{array}$ \\
\hline
\end{tabular}




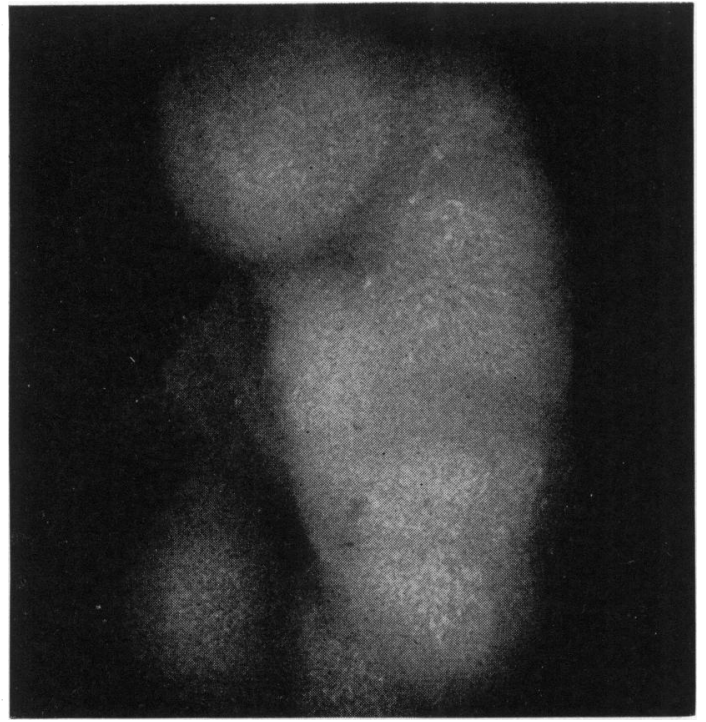

FIG. 4.-Case 1. Post mortem radiograph of kidney showing deposits in the pyramids.

Treatment AND Progress. Treatment with cortisone by injection was started when she was just over 21 weeks old (Table 2); the dose varied but initially was $75 \mathrm{mg}$. daily for four days, and then $50 \mathrm{mg}$. daily. She was fed on National Dried Milk, but no added vitamin D was given. The serum calcium level dropped to $10.4 \mathrm{mg}$. $\%$ five days after starting cortisone, and apart from one raised value of $12.0 \mathrm{mg}$. \% 10 days afterwards, it remained normal (Table 2). While she was on cortisone therapy a calcium balance was attempted but this was abandoned after 42 hours because she developed a severe rectal prolapse. She made slow progress, being difficult to feed, vomiting and failing to gain an adequate weight. A milk mixture which resulted in an intake of not more than $100 \mathrm{mg}$. of calcium daily was given but her anorexia became worse. At the age of 28 weeks she developed diarrhoea and the cortisone was stopped. The diarrhoea

TABLE 2

CASE 1. BLOOD CHEMISTRY BEFORE AND DURING TREATMENT WITH CORTISONE

\begin{tabular}{|c|c|c|c|c|}
\hline Age (Weeks) & Calcium & Phosphate & Phosphatase & Urea \\
\hline $\begin{array}{l}16^{*} \\
17 \\
18 \\
20 \\
21\end{array}$ & $\begin{array}{r}11 \cdot 4 \\
10 \cdot 3 \\
9.8 \\
13 \cdot 3 \\
11.9\end{array}$ & $\begin{array}{l}4 \cdot 2 \\
\frac{9 \cdot 6}{-}\end{array}$ & $\begin{array}{r}13 \\
9 \\
16 \\
-\end{array}$ & $\begin{array}{r}57 \\
66 \\
83 \\
100 \\
27\end{array}$ \\
\hline $\begin{array}{l}22 \\
23 \\
24 \frac{1}{2} \\
25 \frac{1}{2} \\
26 \\
27 \\
28\end{array}$ & $\begin{array}{r}10 \cdot 4 \\
12 \cdot 0 \\
8 \cdot 8 \\
11 \cdot 3 \\
11 \cdot 2 \\
9 \cdot 2 \\
10 \cdot 6\end{array}$ & $\begin{array}{c}\text { Cortisone } \\
5 \cdot 7 \\
3 \cdot 8 \\
\overline{4} \cdot 5 \\
5 \cdot 4 \\
4 \cdot 2 \\
3 \cdot 8\end{array}$ & $\begin{array}{r}1 \\
16 \\
9 \\
8 \\
9 \\
5\end{array}$ & $\begin{array}{l}\overline{75} \\
\overline{84} \\
\frac{47}{50}\end{array}$ \\
\hline
\end{tabular}

* Age on admission.

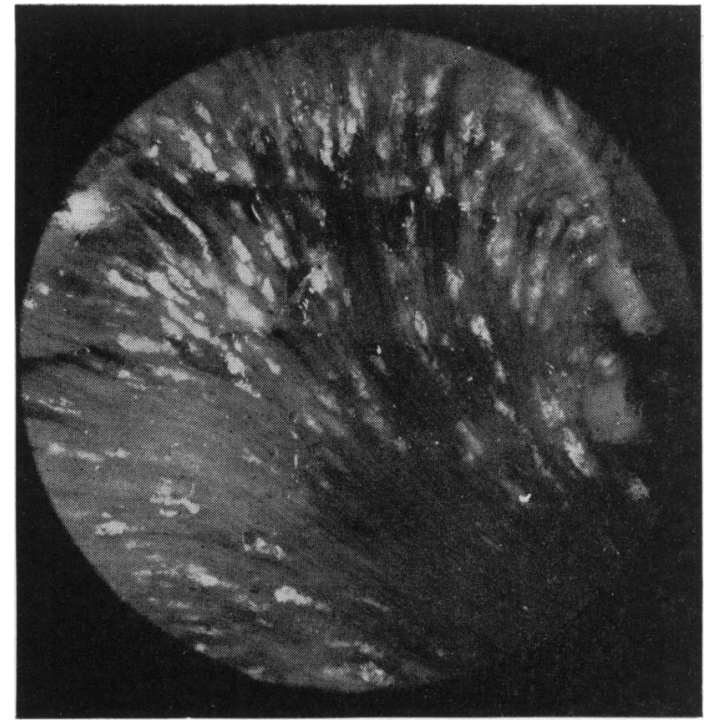

FIG. 5.-Case 1. Macrophotograph of kidney showing deposits in the pyramids $(\times 10)$.

subsided, but her vomiting persisted and the serum calcium levels rose, the highest being $19 \mathrm{mg}$. \% at the age of 9 months. The blood urea varied between 57 and $100 \mathrm{mg}$. \%. Radiographs of the skull and the ends of the long bones showed an increase in density.

Cortisone therapy, $50 \mathrm{mg}$. daily, was started again, and she was discharged from hospital. Her symptoms persisted, however, and both her azotaemia and hypercalcaemia remained unchanged. At the age of 23 months she developed severe whooping cough; her blood urea rose to $150 \mathrm{mg}$. \% and she died two days later.

NeCropsy (Dr. E. H. Bailey). The essential findings were that the kidneys weighed $15 \mathrm{~g}$. (normal $45 \mathrm{~g}$.). Both organs were pale. Thin streaks of calcium-like material were seen in the pyramids of both kidneys (Figs. 4 and 5). The heart weighed $75 \mathrm{~g}$. (normal $55 \mathrm{~g}$.). The left ventricle showed a well marked concentric hypertrophy. The right auricle was dilated and the right ventricle showed a little concentric hypertrophy. The edges of the mitral and tricuspid valves were thickened but there was no macroscopic calcification. The brain itself was normal but the right lateral sinus was completely obstructed by an ante-mortem clot. In the skull the basisphenoid and the bone forming the upper wall of the orbits were thickened. Other organs were normal.

Histology (Dr. S. J. de Navasquez). The heart, stomach, spleen, thyroid, suprarenal glands and bone from the base of the skull were all normal. The liver showed severe passive congestion, and the lungs purulent bronchopneumonia. The intima of the aortic valve showed non-specific fibrous thickening. The cortex of the kidneys showed glomerular atrophy and periglomerular fibrosis (Fig. 6). In the medulla there were focal areas of calcium-like material which extended into and disrupted the collecting tubules in the vicinity 


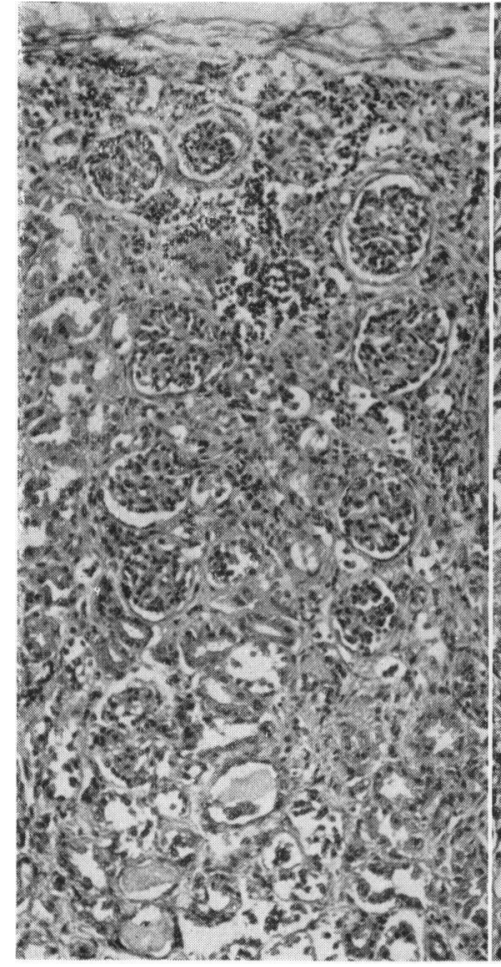

Fig. 6.-Case 1.

Cortex showing glomerular atrophy and periglomerular fibrosis (H. and E. $\times 110)$.

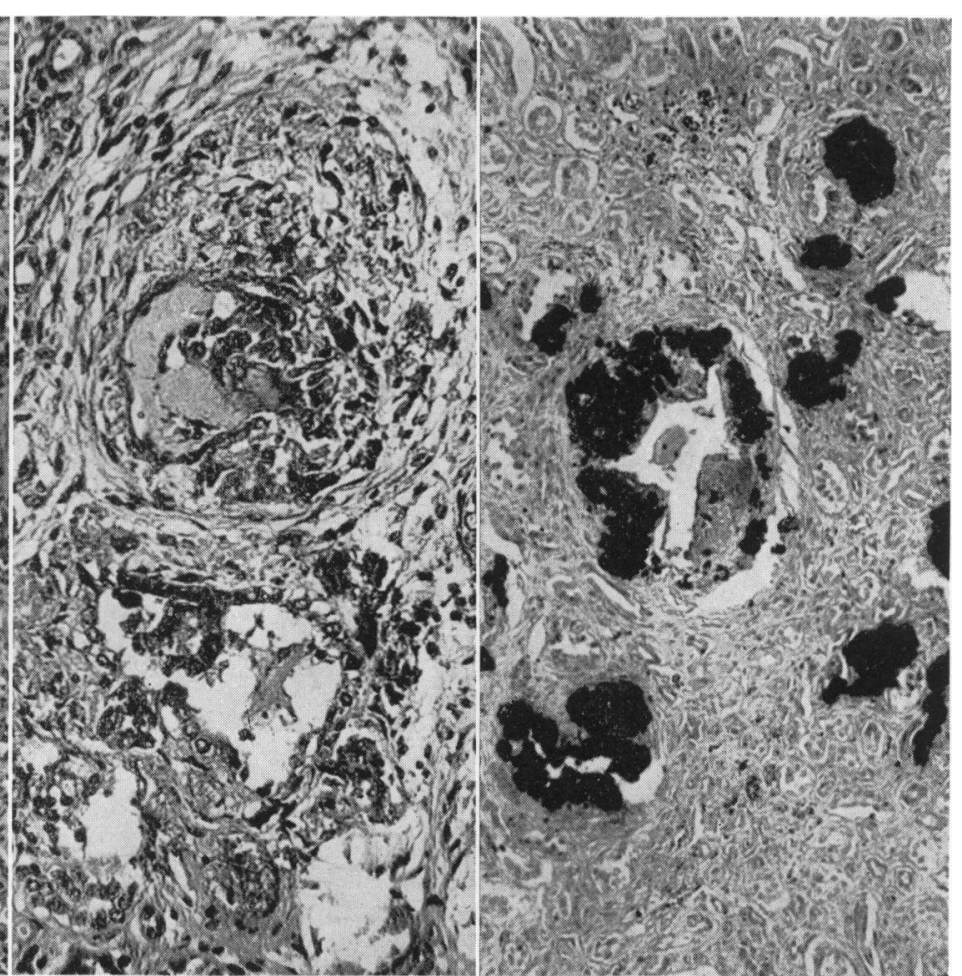

FIG. 7.-Collecting tubules showing intraluminal and subepithelial deposits of calcium-like material with disruption of the epithelium and interstitial fibrosis. (H. and E. $\times 175$.)
FIG. 8.-Medulla showing deposits of calcium-like material in the tubules. (von Kossa $\times 110$.)
(Figs. 7 and 8). In addition, chronic focal pyelonephritis was present.

Case 2. B.D. was the second child of a family of three. Pregnancy was normal and her gestation period was 42 weeks; delivery was uncomplicated and her birth weight was $5 \mathrm{lb} .12 \mathrm{oz}$. She was breast fed for the first two weeks of life but when she was admitted to a hospital for severe conjunctivitis she was fed on half cream National milk. At this time she was noted to have an apical systolic murmur. She was in hospital two weeks and on discharge weighed $6 \mathrm{lb} .8 \mathrm{oz}$.

She progressed fairly well but vomited occasionally. At the age of 3 months her feeds were changed to full cream Cow and Gate milk. One month later she became listless and her vomiting became worse, and she was admitted to the Evelina Hospital. At this time she weighed $9 \mathrm{lb} .12 \mathrm{oz}$. Physical examination showed mild fever $\left(100^{\circ} \mathrm{F}\right.$.), apathy, wasting, and loss of skin turgor. Her facies resembled that of Case 1, but in addition the inner third of her eyebrows was missing (Fig. 9). The pulse was regular at 130/minute and the heart was not enlarged. There was a loud systolic murmur maximal just internal to the apex. The blood pressure was $126 / 70 \mathrm{~mm}$. Hg. There was marked hypotonia of the limb and trunk muscles. Other systems were normal.
INVESTIGATIONS. The results of investigations on admission are shown in Table 1 . The urine contained albumen and an excess number of white cells; the serum calcium and blood urea were both raised. Radiographs showed increased density at the base of the skull, of the periorbital bones and at the ends of the long bones.

Treatment and Progress. Various feeds were tried, but her vomiting and anorexia persisted. She gained only $2 \mathrm{lb}$. in weight over a period of six months. A diet containing not more than $150 \mathrm{mg}$. of calcium daily was given for two months, but although her serum calcium levels became normal after six weeks, her symptoms persisted. Two weeks later, she was given normal milk feeds and this coincided with a gain in weight, which continued until her discharge four months later at the age of 19 months; at this time she weighed $16 \mathrm{lb} .14 \mathrm{oz}$., her hypotonia was less and she was able to sit up unaided. Her facies was unchanged. The serum calcium was $11.6 \mathrm{mg}$. \% and the blood urea $40 \mathrm{mg}$. \%.

She continued to progress very slowly, her weight at 2 years being $18 \mathrm{lb} .2 \mathrm{oz}$. Six months later she was readmitted weighing $19 \mathrm{lb}$. At this time she was beginning to say a few words and was walking with help; her squint was worse but the systolic murmur was now blowing and the systolic blood pressure was $110 \mathrm{~mm}$. $\mathrm{Hg}$. 


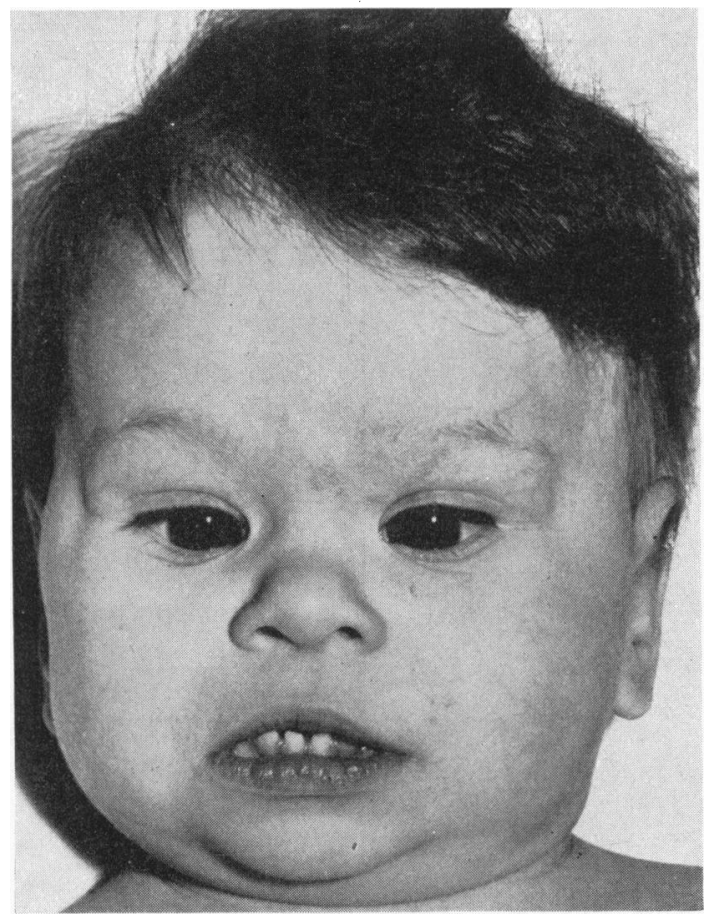

FIG. 9.-Case 2. The facial appearance; note loss of inner third of eyebrows.

The haemoglobin was $9 \mathrm{~g}$. \%, serum calcium $12.6 \mathrm{mg} . \%$, phosphorus $4 \mathrm{mg}$. \%, alkaline phosphatase 9 units (King Armstrong) and urea $65 \mathrm{mg}$. \%. Radiographs of the skull and ends of the long bones showed a decrease in density.

A calcium balance was done when she was $2 \frac{3}{4}$ years old and, following this, cortisone $15 \mathrm{mg}$. b.d. was given by injection. She became brighter, her appetite increased and she put on weight rapidly and consistently; the serum calcium fell to $7.8 \mathrm{mg}$. \% but the blood urea remained elevated at $48 \mathrm{mg}$. \% (Fig. 10).

Two months later the systolic murmur was less loud. The calcium balance was repeated while she was taking cortisone. She was discharged at the age of 3 years taking cortisone $25 \mathrm{mg}$. daily by mouth; this was continued for seven months. At the age of 4 years she weighed $24 \mathrm{lb}$. and was about 22 inches tall; her facies was unchanged but the systolic murmur was barely audible; the serum calcium was $9.8 \mathrm{mg}$. $\%$ and the blood urea $43 \mathrm{mg}$. \%. Radiographs of her skeleton still showed some increase in density. Her I.Q. was 40.

Case 3. The clinical features of this patient have been already described (Schlesinger et al., 1956). Briefly, vomiting and anorexia began when he was 11 months old. He was investigated but no firm diagnosis was made until the age of 2 years when he was seen by Dr. Philip Evans who observed the facies, physical and mental retardation and a loud systolic murmur. The

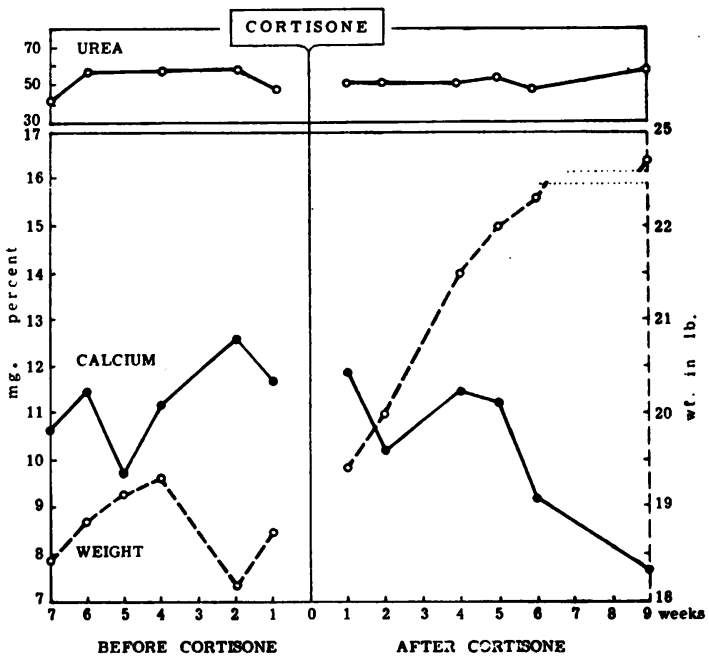

Fig. 10.-Case 2. Response to cortisone.

main investigations are shown in Table 1. The blood urea was $133 \mathrm{mg}$. \%, serum calcium $12.4 \mathrm{mg}$. \% and blood cholesterol $320 \mathrm{mg}$. \%. The base of the skull and periorbital bones showed moderate increase in density.

Over the course of the next few months he began to improve slowly, the vomiting and anorexia became less and he began gaining weight. He was seen again at the age of 5 years, because of attacks of abdominal pain. He was a mentally retarded child whose behaviour resembled that of a 2-year-old; the facies and the squint were unchanged. No systolic murmur was present. Serum calcium, phosphorus and phosphatase were normal, but the blood urea was $73 \mathrm{mg}$. \% and the blood cholesterol $302 \mathrm{mg}$. \%; the urine, radiograph of the skull and intravenous pyelogram were normal and the bone age corresponded with the chronological age.

Case 4. P.B. was a second child; pregnancy and delivery were normal. His birth weight was $7 \mathrm{lb} .3 \mathrm{oz}$. As his mother had a history of tuberculosis he was never breast fed. For the first four months he was fed on half cream milk and subsequently on full cream milk. At the age of 4 months he began to vomit and the National Cod Liver Oil Compound (800 units of vitamin D), which he had been taking, was omitted. He continued to vomit and lose weight and at the age of $5 \frac{1}{2}$ months he was admitted to a hospital. Examination then showed a fairly fit-looking infant with a normal facies; his forehead was prominent, and his temples were narrow. No physical signs were present except those of mild dehydration. His weight was $14 \mathrm{lb}$.

INVESTIGATIONS. The results of investigations are shown in Table 1. The urine was infected with Esch. coli; the serum calcium and blood urea were normal, but the plasma chloride was raised and the bicarbonate lowered.

Treatment and Progress. Subsequent examination of the urine did not confirm the presence of an infection. 


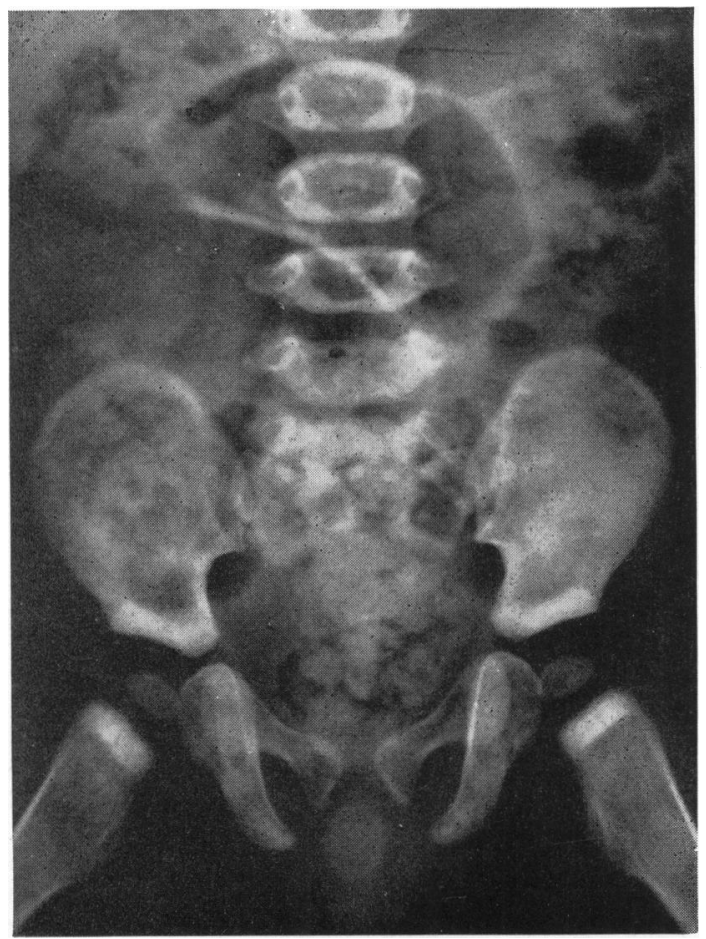

Fig. 11.-Case 4. Increased density adjacent to hip joints, of the iliac crests and of the superior and inferior borders of the lumbar vertebrae.

While in hospital he developed a series of upper respiratory infections. He vomited when he was fed on full cream milk, but when this was changed to half cream no vomiting occurred. He was discharged symptomless taking half cream milk. No firm diagnosis was made.

He progressed slowly until the age of 7 months when vomiting recurred and he developed severe constipation. He was admitted to Guy's Hospital. On examination there were no physical signs except those of constipation. The results of investigations are shown in Table 1.

In view of the previous and present findings, it was thought likely that he had infantile renal acidosis with hypercalcaemia and he was treated with a mixture of $10 \mathrm{gr}$. sodium citrate and $2.5 \mathrm{gr}$. of citric acid four times daily. He began gaining weight and the plasma bicarbonate rose to $26 \mathrm{mEq} / 1$. and the plasma chloride fell to $104.6 \mathrm{mEq} / \mathrm{l}$. When the alkali was discontinued the plasma bicarbonate fell to $16.2 \mathrm{mEq} / \mathrm{l}$. and the chloride rose to $111 \mathrm{mEq} / \mathrm{l}$. Treatment with alkali was reintroduced and he responded well, gaining $12 \mathrm{oz}$. in the first week.

Two months later he developed severe bronchitis and was readmitted. Examination at this time showed no physical signs additional to those of bronchitis; the systolic blood pressure was $110 \mathrm{~mm}$. $\mathrm{Hg}$; the blood urea was $130 \mathrm{mg}$. \% and the serum calcium $9 \mathrm{mg}$. \%. The $\alpha_{2}$ and $\beta$ globulins were increased. Radiographs of the

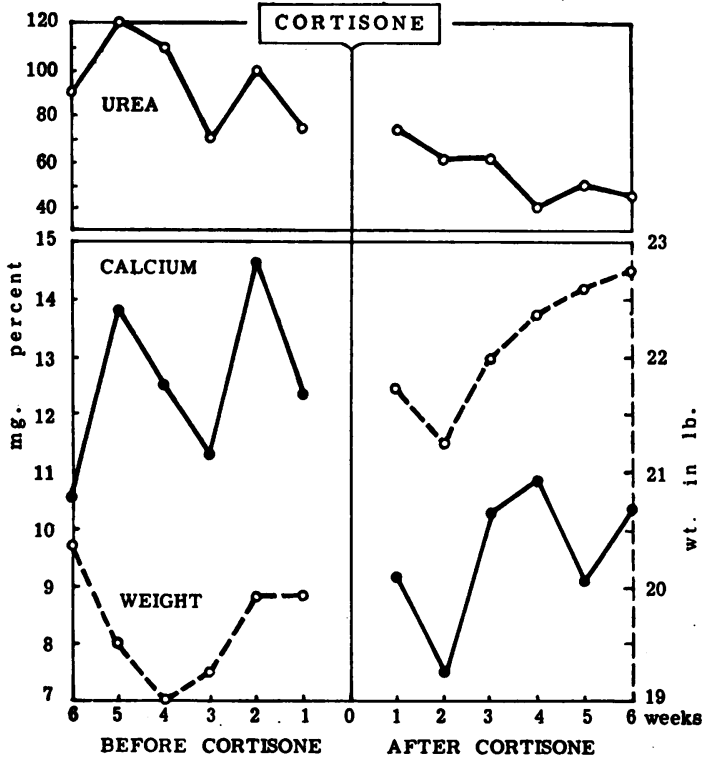

Fig. 12.-Case 4. Response to cortisone.

skull, long bones, vertebrae and pelvis showed increased density (Fig. 11). Subsequent serum calcium levels remained high, rising to $15.8 \mathrm{mg}$. $\%$ and $14.6 \mathrm{mg}$. \% on two occasions. He vomited periodically and gained weight slowly. A milk containing not more than $100 \mathrm{mg}$. of calcium daily was given for two months without appreciable effect clinically or biochemically. A calcium balance was performed at this stage, and following this he was given cortisone by injection, $25 \mathrm{mg}$. b.d. He responded well both clinically and biochemically; his serum calcium fell to $7.6 \mathrm{mg}$. \% later rising to within normal limits (Fig. 12). He was discharged taking the same dose of cortisone by mouth. Three months later the calcium balance was repeated while he was taking cortisone.

His subsequent progress was good and he gained weight satisfactorily. The cortisone was stopped after 10 months. He continued to do well and at the age of 43 years he weighed $38 \mathrm{lb}$.; the blood pressure was $110 / 70 \mathrm{~mm}$. $\mathrm{Hg}$ and no physical signs were present; there was no evidence of mental retardation. The urine was acid and normal. The blood urea was $44 \mathrm{mg}$. \%, serum calcium $11 \mathrm{mg}$. \% and phosphate $3.7 \mathrm{mg}$. \%.

Radiologically the long bones were normal but the base of the skull and periorbital bones still showed some increase in density.

\section{Calcium Balance Studies}

Balance Methods. The patient was equilibrated on a constant calcium intake for three days and thereafter stools and urine were collected between stool carmine markers over a period of four days. The type of feed and calculated intake of vitamin D 
are indicated in Table 3. A metabolic bed was used, and the stools were collected into cellophane-lined containers. In girls the urine was collected through a vulval mould and in boys through Paul's tubing. All receptacles for stools and urine were previously rinsed with distilled sterile water. Duplicate aliquots of stools, urine and a homogenate of a duplicate diet were digested with fuming nitric and perchloric acids. The digest was made up to volume and insoluble fatty acids were filtered off. After adjustment of $\mathrm{pH}$, calcium was precipitated with excess oxalate and estimated by titration with standard potassium permanganate solution.

Table 3 shows the results of the balances. Cases 2 and 4 each had two balances, before and after cortisone therapy. Balances were attempted in Cases 1 and 2 in the early stages of their illness but were not completed as they were badly tolerated. Case 1 had a short balance lasting 42 hours while she was on cortisone, and although the results have been recorded, interpretation must be especially cautious. However, the figure of $38 \%$ retention is similar to that reported by Forfar, Balf, Maxwell and Tompsett (1956) and Morgan, Mitchell, Stowers and Thomson (1956) in affected infants of the same age while taking cortisone. The daily retention of calcium in Case 2 was $30 \%$ which is between one and a half and three times more than normal at this age (Daniels, 1941; Watson, McGuire, Meyer and Hathaway, 1945; McLean, Lewis, Jensen, Hathaway, Breiter and Holmes, 1946; Irving, 1950). The daily retention in Case 4 was about normal when expressed as a percentage of intake but in absolute figures (137 $\mathrm{mg}$. and $248 \mathrm{mg}$.), both children retained between one and a half and three times normal (Shohl, 1939; Holmes, 1945; Mitchell, Hamilton, Steggerda and Bean, 1945). Schlesinger, Butler and Black (1952) and Forfar et al. (1956) in affected children of similar age reported daily retentions of $74 \mathrm{mg}$. and $126 \mathrm{mg}$. of calcium $(7 \cdot 7 \%$ and $16 \%$ of intake).

Effect of Cortisone. The effect of cortisone on calcium retention is shown in Table 3. In Case 2 calcium retention increased from $30 \%$ to $37 \%$ and in Case 4 from $20 \%$ to $33 \%$. The total intake varied in our children, but Watson et al. (1945) found that similar variations of intake did not influence the percentage retentions in normal children. The effect of cortisone on calcium retention which we observed was similar to that found by Fletcher (1957) in a boy of 3 years in whom the faecal calcium decreased when he was given $15 \mathrm{mg}$. of cortisone daily. However, although others (Bonham Carter, Dent, Fowler and Harper, 1955; Forfar et al., 1956; Morgan et al., 1956) have found that cortisone increases the faecal calcium and therefore reduces calcium retention, their studies were on younger patients in whom cortisone therapy had been of shorter duration. Nevertheless, we cannot satisfactorily account for the difference in these findings, especially as cortisone was so effective in reducing the serum calcium levels (Figs. 10 and 12).

\section{The Facies}

The unusual facial appearance was recognized by Butler (1951) and Fanconi (1951), and it has been used to help distinguish the severe from the mild type. How soon after birth it develops is unknown. The mother of B.G. told us that she thought the face was 'queer looking' at birth, and it was sufficiently characteristic at 4 months of age for the clinical diagnosis to be made (Joseph, 1956).

The facies in this disease has received less attention than some of the other features, but since it usually indicates severity, it is both an important diagnostic and prognostic sign.

There have been too few examples observed for all the facial variations and combinations to be known, and for a great many generalizations to be made, and the following notes are no more than an attempt to focus attention on some of the changes. One of the difficulties we have encountered is our ignorance of the range of normal, if any face can be called normal. The facial appearance in this disease is due to the presence of a combination of features, but we do not know which particular

TABLE 3

CALCIUM BALANCES IN CASES 1, 2 AND 4

\begin{tabular}{|c|c|c|c|c|c|c|c|c|c|c|c|}
\hline Case & Age (yr.) & Diet & $\begin{array}{l}\text { Daily } \\
\text { Vit. D } \\
\text { Intake } \\
\text { (units) }\end{array}$ & $\underset{(\mathrm{mg} . \%)}{\text { Calcium }}$ & $\begin{array}{l}\text { Urea } \\
\text { (mg.) }\end{array}$ & $\begin{array}{c}\text { Daily } \\
\text { Cortisone } \\
\text { (mg.) }\end{array}$ & Intake & $\begin{array}{c}\text { Calcium } \\
\text { Faeces }\end{array}$ & $\begin{array}{l}\text { (mg. da } \\
\text { Urine }\end{array}$ & \multicolumn{2}{|c|}{ Retention $\%$} \\
\hline 1 B.G. & $\frac{1}{2}$ & Milk & 700 & $11 \cdot 2$ & 84, & 50 & 1,255 & 700 & 72 & 473 & 38 \\
\hline $\begin{array}{l}2 \text { B.D. } \\
4 \text { P.B. }\end{array}$ & $\begin{array}{l}3 \frac{1}{2} \\
3 \frac{1}{2}\end{array}$ & $\begin{array}{l}\text { Mixed } \\
\text { Mixed } \\
\text { Milk, egg }\end{array}$ & $\begin{array}{l}12 \\
44 \\
66\end{array}$ & $\begin{array}{r}11 \cdot 7 \\
9 \cdot 2 \\
11\end{array}$ & $\begin{array}{l}41 \\
31 \\
47 \\
93\end{array}$ & 50 & $\begin{array}{r}455 \\
1,066 \\
1,208\end{array}$ & $\begin{array}{l}255 \\
512 \\
890\end{array}$ & $\begin{array}{r}63 \\
119 \\
70\end{array}$ & $\begin{array}{c}137 \\
373 \\
248\end{array}$ & $\begin{array}{l}30 \\
37 \\
20\end{array}$ \\
\hline " & $2 \xi$ & & & $\begin{array}{l}13 \\
12 \cdot 1 \\
14 \cdot 1\end{array}$ & $\begin{array}{l}73 \\
80 \\
60\end{array}$ & 50 & 702 & 342 & 123 & 237 & 33 \\
\hline
\end{tabular}




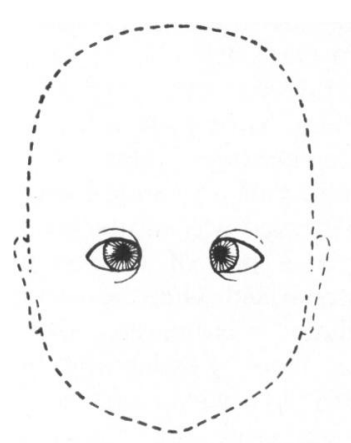

a

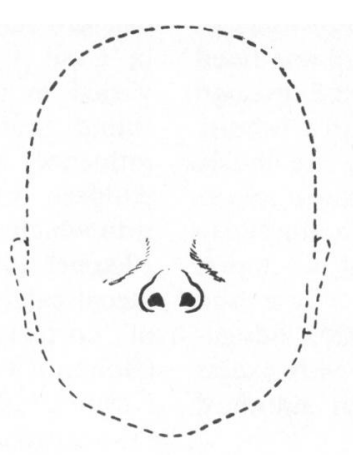

b
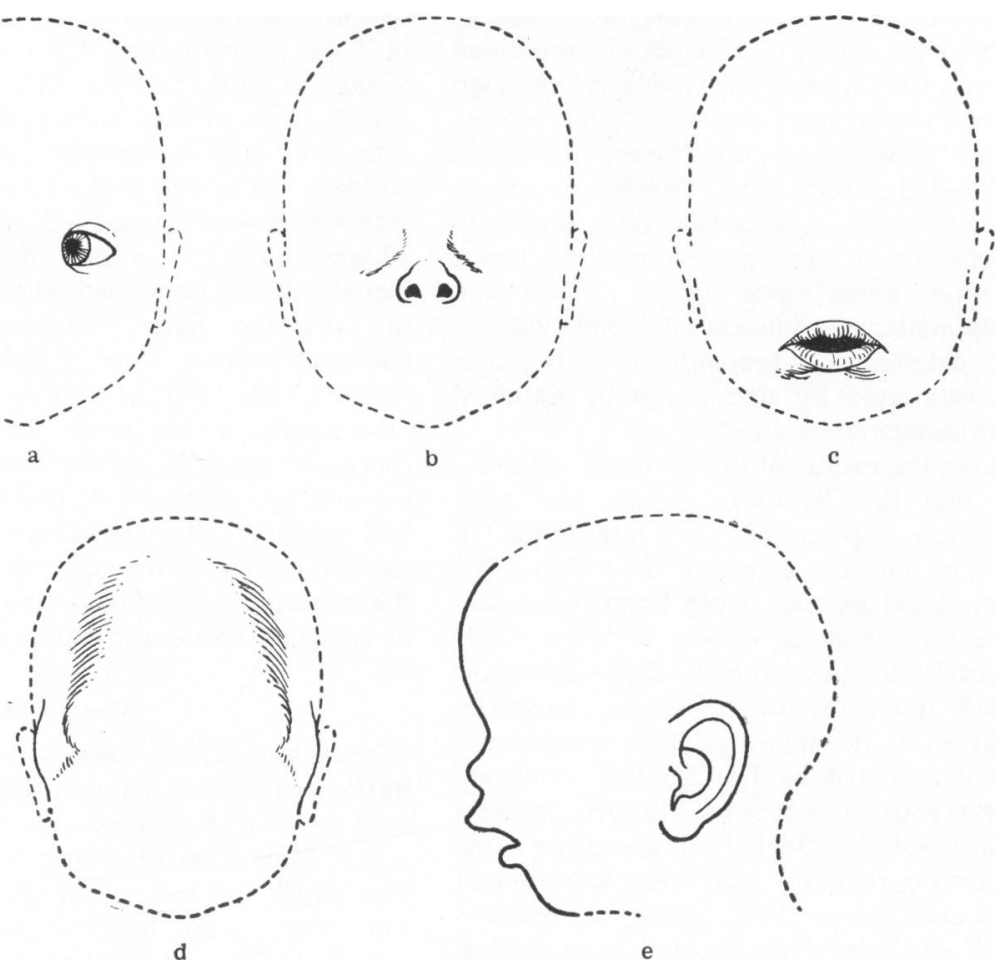

FIG. 13.-Components of the facies.

combination is necessary to produce the facies; indeed it is likely that different combinations will affect the facies, and this is probably what occurs.

Lowe et al. (1954) have described the facies as elfin-like; although we agree that this applies to the general shape of their face, it disregards their expression of misery and irritability. Surely elves have a sprightly air:

'Couronnés de thym et de marjolaine

Les Elfes joyeux dansent sur la plaine.'

\section{Leconte de Lisle}

The Individual Facial Features. Epicanthic folds and commonly a concomitant squint are present (Fig. 13a). The nose is pinched and retroussé, with the nostrils pointing forwards (Fig. 13b); because there is some filling in at the sides of and across the nose, the appearance has been likened to that of a pekinese dog (British Medical Journal, 1954). The upper lip is prominent and appears loose (Fig. 13e); it lacks the usual bow and the pars villosa may persist (Fig. 13c). The mouth is sometimes asymmetrical and is generally kept open, the lower lip hanging slackly. The temples are narrow (Fig. 13d).
The profile is affected by the receding chin and by the rounded and sometimes prominent forehead (Fig. 13e). The ears may be large but are normally placed (Fig. 13e).

The ears have been described as being low set (Butler, 1951; Schlesinger et al., 1952) but we think they appear so because these children frequently adopt a 'chin-up' position (Fig. 14). This deception is added to if the ramus of the mandible is short or if its angle with the body of the mandible is more acute than normal. The ear may also appear low if the vertex of the skull is deep; this was well illustrated when the father of an affected boy said he thought that his son's head was high rather than that his ears were low. Finally, a relative increase in the amount of the pinna below the meatus will make the ear appear low in the same way as a large ear may.

The profile of these infants runs downwards and backwards and therefore the Frankfurt line does not form even an approximate right angle with the profile. Although the ear appears low the external auditory meatus maintains a normal relationship with the base of the skull (Fig. 15). 

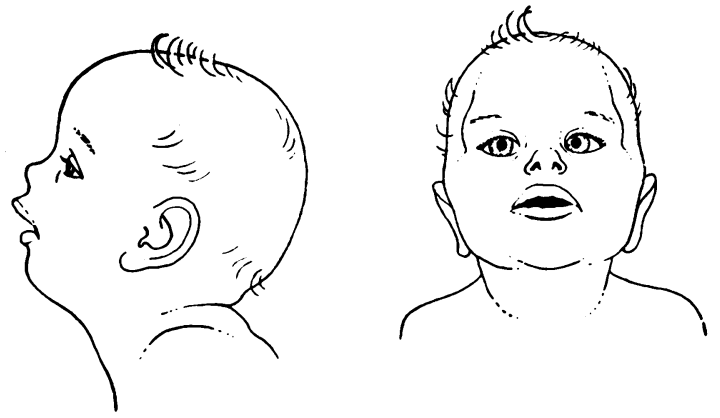

FIG. 14. - The ears appear low because the head is held extended
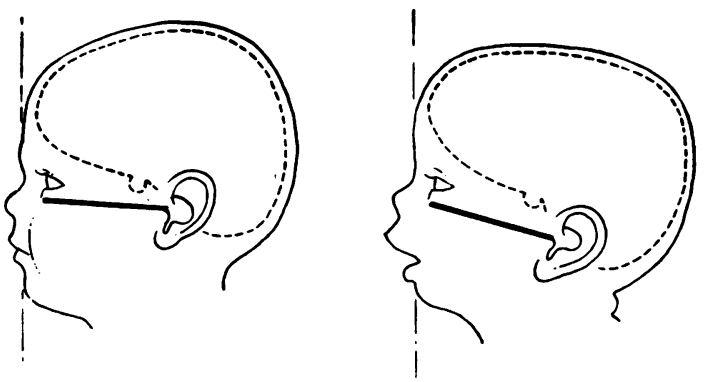

FIG. 15.- The Frankfurt line has been drawn and shows that the external auditory meatus has a normal relationship to the base of the skull.

place them in one or other category. We are uncertain which criteria are valid in order to classify the affected infant. Transient and benign is no help as three infants who conformed to this type came to necropsy (Rhaney and Mitchell, 1956; Morgan et al., 1956). Systolic murmurs may be present in both types; they were recorded in the simple type by Lowe et al. (1954), Creery and Neill (1954) and MacDonald and Stapleton (1955), but were absent in some of the severe cases collected by Schlesinger et al. (1956). Hypertension is also unreliable; MacDonald and Stapleton (1955) reported its presence in a simple case, while Creery (1953) and Lowe et al. (1954) found normal readings in two severe cases. Radiological changes in the bones are not absolute but increased density of the base of the skull has only been described in the severe forms, although it was not present in three patients who died (Rhaney and Mitchell, 1956). The characteristic facies has been described as only occurring in the severe form but Rhaney and Mitchell (1956) reported its absence in their three fatal cases. It is probably too early to evaluate the incidence of mental retardation, but in general the survivors in the simple group have developed normally whereas the few survivors of the severe form have been grossly retarded. The facies and bone changes in the skull usually occur together and indicate severity, with renal impairment and possible mental retardation. Cases 1,2 and 3 had these changes and Case 1 died and Cases 2 and 3 are both grossly retarded (I.Q. 40). But absence of skull changes and of the facies does not necessarily indicate a good prognosis, as shown by the deaths reported by Rhaney and Mitchell (1956) and Morgan et al. (1956).

Creery (1953) has suggested that all grades of idiopathic hypercalcaemia occur and later others have supported this conception (Russell and Young, 1954; Lightwood, 1955). Case 4 was an example reports of infants with hypercalcaemia, and some have had features which have made it difficult to 
of an intermediate grade. He resembled the simple type by the presence of a raised $\alpha_{2}$ globulin, and the absence of abnormal facies, of hypertension, of a systolic murmur and of mental retardation. On the other hand, he resembled the severe type by the presence of bone changes in the skull, vertebrae and pelvis, by a raised serum cholesterol and by his slow recovery. Additionally he had some of the changes seen in renal acidosis. Lightwood (1952) and Payne (1952) reported that an associated renal acidosis was occasionally present in simple hypercalcaemia and Lightwood (1955) found this in six of 50 cases. In none of these patients, however, were there bone changes such as those found in Case 4.

As it is now recognized that the prognosis is not always good in the simple or so-called benign cases, it is suggested that the term 'benign' should no longer be used.

\section{Necropsy Findings}

The findings at necropsy and the histological changes have been described and discussed fully by Dawson et al. (1954), Lowe et al. (1954) and Schlesinger et al. (1956). Darmady and Stranack (1957, 1958) have microdissected a number of these kidneys and consider that the focal areas of deposit are probably a phosphate protein complex, and should at the moment be referred to as 'calcium-like'.

The changes in the kidneys found in Case 1 were similar to those previously reported. Although nephrocalcinosis was not diagnosed before death, calcium-like material was clearly seen in the cut surface of the kidney macroscopically and radiologically (Figs. 4 and 5). Darmady and Stranack (1958) have fully described their findings on microdissection of the kidney in Case 1 and we are grateful to them for allowing us to use their report and microphotograph. Briefly, they found focal areas of calcium-like material adherent to the basement membrane and projecting laterally from the proximal tubule wall. Similar areas were seen in the distal and collecting tubules (Fig. 16).

\section{Conclusion}

The cause of infantile hypercalcaemia and an explanation of many of its clinical features remain unanswered. The exact incidence of the condition is unknown but Morgan et al. (1956) have pointed out that in Dundee between 1953 and 1955 it accounted for $4.6 \%$ of all medical admissions of children aged 6 to 12 months, ranking fourth in frequency after respiratory infections, feeding difficulties and otitis media. We do not know whether its incidence is diminishing, but if sensitivity

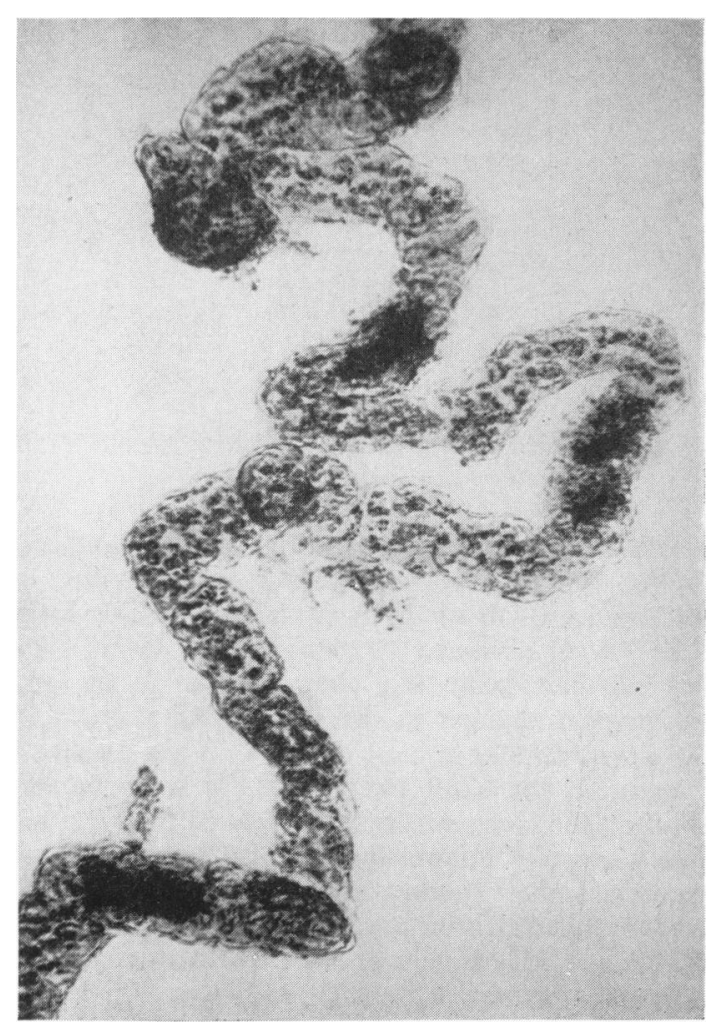

Fig. 16.-A portion of proximal tubule shows a plaque of calciumlike material adherent to the basement membrane and further areas are seen lower in the nephron. At the bottom left hand corner of the picture an albuminous case is seen lying in the lumen of the tubule. The architecture of the proximal tubule is normal. $(\times 280$. $)$

to vitamin D (Lancet, 1954) is an important contributory factor, then the recent recommendation (Her Majesty's Stationery Office, 1957) that the vitamin D content of National Dried Milks and Cod Liver Oil Compound should be halved is likely to reduce the incidence of a disease which may cause physical and mental retardation, and sometimes death.

\section{Summary}

The clinical, radiological and biochemical features of four patients with severe infantile hypercalcaemia are described. In addition, one of the patients had renal acidosis.

Three patients were treated with cortisone, and in two the response was good; the third died and the results of necropsy are discussed. Balance studies on these three patients reveal an increased retention of calcium, and cortisone was found to augment this retention.

The individual features of the facies are illustrated 
and discussed. It is suggested that patients having the characteristic facies are usually severely affected and are likely to have sequelae of mental retardation and renal insufficiency.

The types of infantile hypercalcaemia are discussed and it is suggested that the mild and severe types should not be considered separate syndromes.

Cases 1, 2 and 3 were under the care of Dr. P. R. Evans and Case 4 was under the care of Dr. R. C. Mac Keith. We thank Dr. W. H. H. Merivale for help with the calcium balances, and Dr. J. Dow for help with the interpretation of the radiographs. Miss S. Treadgold of the Medical Illustration Department contributed much to the section on the facies, and we thank her for her help and for the drawings. The remaining illustrations were made by the Photographic Department to whom we are indebted.

\section{REFERENCES}

Bongiovanni, A. M., Eberlein, W. R. and Jones, I. T. (1957). New Engl.J. Med., 257, 951 .

Bonham Carter, R. E., Dent, C. E., Fowler, D. I. and Harper, C. M. (1955). Arch. Dis. Childh., 32, 399.

British Medical Journal (1954). Leading article, 2, 1155.

Butler, N. R. (1951). Proc. roy. Soc. Med., 44, 296.

Creery, R. D. G. (1953). Lancet, 2, 17.

and Neill, D. W. (1954). Ibid., 2, 110.

Daeschner, G. L. and Daeschner, C. W. (1957). Pediatrics, 19, 362.

Daniels, A. L. (1941). Amer. J. Dis. Child., 62, 279.

Darmady, E. M. and Stranack, F. (1957). Brit. med. Bull., 13, 21. - (1958). In the press.
Dawson, I. M. P., Craig, W. S. and Perera, F. J. C. (1954). Arch. Dis. Childh., 29, 475 .

Fanconi, G. (1951). Schweiz. med. Wschr., 81, 908.

Girardet, P., Schlesinger, B. E., Butler, N. R. and Black, J. A. (1952). Helv. paediat. Acta, 7,314 and 335 .

Fletcher, R. F. (1957). Arch. Dis. Childh., 32, 245.

Forfar, J. O., Balf, C. L., Maxwell, G. M. and Tompsett, S. L. (1956). Lancet, 1, 981 .

Her Majesty's Stationery Office (1957). Report of the Joint SubCommittee on Welfare Foods.

Holmes, J. O. (1945). Nutr. Abstr. Rev., 14, 597.

Irving, J. T. (1950). S. Afr. med. J., 24, 601 .

Joseph, M. C. (1956). Brit. med. J., 1, 1112

Kendall, A. C. (1957). Ibid., 2, 682.

Lancet (1954). Leading article, $2,127$.

Leconte de Lisle, C. M. R. (1925). Oxford Book of French Verse, p. 442. St. John Lucas.

Lightwood, R. (1932). Arch. Dis. Childh., 7, 193.

(1935). Ibid., 10, 205.

(1952). Ibid., 27, 302 .

(1955). Rev. port. Pediát., 18, 335.

- and Stapleton, T. (1953). Lancet, 2, 255.

Lowe, K. G., Henderson, J. L., Park, W. W. and McGreal, D. A. (1954). Lancet, 2, 101.

MacDonald, W. B. and Stapleton, T. (1955). Acta Paediat. (Uppsala), $44,559$.

McLean, D. S., Lewis, G. K Jensen, E., Hathaway, M., Breiter, H. and Holmes, J. O. (1946). J. Nutr., 31, 127.

Morgan, H. G., Mitchell, R. G., Stowers, J. M and Thomson, J. (i956). Lancet, 1, 925 .

Mitchell, H. H., Hamilton, T. S. Steggerda, F. R. and Bean, H. W. (1945). J. biol. Chem., 158, 625.

Payne, W. W. (1952). Arch. Dis. Childh., 27, 302.

Rhaney, K. and Mitchell, R. G. (1956). Lancet, 1, 1028.

Russell, A. and Young,.W. F. (1954). Proc. roy. Soc. Med., 47, 1036.

Schlesinger, B., Butler, N. and Black, J. (1952). Helv. paediat. Acta, 7,335 .

, (1956). Brit. med. J., 1, 127.

Shohl, A. T. (1939). Mineral Metabolism, p. 50. New York.

Sissman, N. J. and Klein, R. (1956). Clin. Res. Proc., 4, 36.

Stapleton, T. and Lightwood, R. (1953). Lancet, 2, 255.

Watson, E. K., McGuire, E. W., Meyer, F. L. and Hathaway, M. L (1945). J. Nutr., 30, 259. 